\title{
Assessment of Sustainable Development in Secondary School Economics Students According to Gender
}

\author{
Javier Cifuentes-Faura *๑), Ursula Faura-Martínez $₫$ and Matilde Lafuente-Lechuga $₫$ \\ Faculty of Economics and Business, University of Murcia, Campus Universitario, 11, 30100 Murcia, Spain; \\ faura@um.es (U.F.-M.); mati@um.es (M.L.-L.) \\ * Correspondence: javier.cifuentes@um.es
}

Received: 28 May 2020; Accepted: 30 June 2020; Published: 2 July 2020

check for updates

\begin{abstract}
Environmental education is one of the most effective means of raising public awareness of the need to preserve the environment, and therefore plays a key role in raising awareness and conserving the environment. Teachers also play an important role in achieving these sustainable objectives. Economic decisions are intimately linked to and affect the sustainable development to a large extent, hence the importance of the subject of economics in achieving sustainability. The minimum contents established by the educational law on these aspects related to sustainability have been revised. Through a survey, the differences in knowledge, attitudes, and behaviors related to sustainable development are analyzed from a gender perspective. It is detected that, in general, women have a greater knowledge of environmental issues and more sensitivity, with a greater commitment to recycling and changing lifestyles.
\end{abstract}

Keywords: sustainability; education; gender

\section{Introduction}

Educating about sustainability has as a challenge schooling about the limits of our environment and vital space, to show how to understand and control it. Any discipline that is part of the educative system should deal with some of the aspects of sustainability (social, economic, environmental), showing the relationship between society and nature and illustrating how global well-being can only be reached if we carry it out together. A great challenge for education is to find a channel and a way of learning that help us understand and resolve problems linked to sustainability.

The concept of sustainability was introduced in 1970 through the World Commission on Environment and Development [1]. Since then, the progress on sustainability has always aimed to give answers to the problems we find nowadays, and education plays a role of prime importance. In the 1990 Talloires Declaration the key role education plays became evident. The challenges of mainstreaming sustainable development (SD) in education were discussed at the 1992 United Nations Conference on Environment and Development in Rio de Janeiro, which resulted in Agenda 21, which aimed to bring all levels of education into line with sustainability. This program was an important milestone to help implant SD into the study programs of all levels of education, although its results in the education area were not all satisfactory. It was at the World Summit on Sustainable Development in 2002 that concrete SD targets were set at all levels.

Gradually, education has become more important in the fight against climate change and for the development of sustainable practices. This is reflected in the publication of the Decade of Education for Sustainable Development 2005-2014, taking into account that "education alone cannot achieve a more sustainable future; however, without education and learning for sustainable development, we will not be able to reach that goal" [2]. 
Another important milestone is Agenda 2030 for Sustainable Development, which established 17 Sustainable Development Goals (SDGs) that aim to eradicate poverty, promote quality education, reduce inequalities, create sustainable cities and communities, and ultimately protect the planet.

These are just some of the most relevant summits or conferences organized worldwide in support of sustainability. The question is whether these educational policies are accompanied by concrete actions, or are merely theoretical arguments whose real application in educational life leaves much to be desired. And in the case that they are being carried out, it would be convenient to know the real scope of these actions. At times, a gap is evident between the formulation of educative policies that frequently arise from supranational organizations, which are implicitly adopting the top-down model, and their applications in educational practice [3].

In order to bring SD into the classroom, it is necessary to carry out a profound transformation in traditional teaching methodology, focused on the acquisition of knowledge and skills for professional practice [4]. Future professionals now need to be trained in values, attitudes, and behaviors in line with sustainability competencies [5-15]. The role of teachers is critical in strengthening sustainability awareness and knowledge among students [16-18].

Diverse studies have focused on establishing the factors that are directly related to students and sustainability, through knowledge measurement, attitudes, and the relative behaviors towards SD. Authors of [19-21] analyzed the implementation level of sustainability within compulsory education in Manitoba, Canada. Authors of [22,23] as well as [24] evaluated the effect of the sustainable education on the environmental awareness of the primary school students from Sweden. Authors of [25] analyzed the attitudes toward SD of Italian university students, and [26] did the same for the university students from Cyprus. Authors of [27] established the knowledge, attitudes, and behaviors of the university students from the United Arab Emirates regarding SD education.

In Spain, in the particular case of high school studies, no research has been conducted, to our knowledge, on the comprehension, attitudes, or behavior regarding SD of students in the field of economics. It must be considered that the economy is intimately linked to the concept of sustainable development, so it is important to focus on sustainability within the classroom (circular economy-green economy, for example), as these students are the agents of the sustainable future. Furthermore, according to various studies [28-30] women are more aware of and involved with sustainability, being more aware of the need to act, having a better attitude towards the challenge of combating climate change. This research is based on the adult population, and we should know what happens with today's youth if this gender gap in knowledge and understanding of SD already exists. The main objective of this study is to provide information on all these aspects.

\subsection{The Role of the Economy in Sustainability}

The economy is intimately linked to the concept of sustainable development. Within the context of SD, one of the main actions that the economy aims to achieve is to eradicate poverty, ensuring a better quality of life without affecting natural resources [31,32]. The definition of sustainability and its scope as a tool for transforming the development model based on the market economy and the intense exploitation of the planet's natural resources was analyzed by López Pardo, who considered that "although we are faced with a concept (sustainability) of contrasting intellectual and institutional influence, sustainable development lacks the real power to change the hegemonic development model, which causes environmental impact on the planet, unless it is really tackled and implemented from a 'strong' sustainability approach" [33] (p.123).

For several years, the need to adopt a green economy has been promulgated [34-36], as well as the need to develop a model of the circular economy $[37,38]$. The green economy contributes to maintaining a healthy environment and making appropriate use of the ecosystem. The outcome document of the Rio+20 Conference recognizes that "green economy in the context of sustainable development and poverty eradication will enhance our ability to manage natural resources sustainably and with lower negative environmental impacts, increase resource efficiency and reduce waste" [39] (p.12). In this 
context, the model of the circular economy, which evolved from the concept of sustainability [40], arises to care for and preserve the environment through the implementation of sustainable strategies in the economy and society.

Likewise, the circular economy model is being promoted by different institutions and governments worldwide, with the aim of "promoting the decoupling of economic growth and increased resource consumption" [41], maintaining the added value of products for as long as possible while reducing waste to minimum levels [42,43]. The circular economy model allows products to be used when they reach the end of their useful life through reuse to generate added value [41,44]. This leaves behind the model of linear economy centered on "take-use-pull."

Education plays a relevant role in training future professionals, as they will be the decision makers who will influence society as a whole from different spheres and levels of responsibility. The incorporation of activities that introduce sustainability into high school subjects, specifically in economics, will mean that students will contribute to preserving the environment and improving the general standard of living, while at the same time acquiring appropriate codes of behavior that they will be able to put into practice when making future decisions in their professional or personal life.

Economic decisions taken in this area will have a significant impact not only on the environment, but also on the economy and society. In this regard, authors of [45], claim: "economic production models that do not incorporate respect for environmental well-being and social cohesion and justice contribute to global warming, to violations of human rights as well as to the increase of the cultural bigotry that would lead us to a changing time, absent of certainty and unforeseen, carrying chaos and ambivalence" (p.27). It is important that future university students gain skills of an economic nature that would allow them to advance the complex and at the same time necessary development of the sustainable human being. These should be achieved through the curricula of the subjects of the economic area.

When reviewing the economics curriculum of the first and second years of Bachillerato in Spain (Bachillerato corresponds in Spain to the two years prior to entrance into the University), according to the Royal Decree 1105/2014, the subject of economics of first year Bachillerato is related to the economic content of the environment in block 1, called "Economics and Scarcity: The organization of economic activity," and in the last block, "Economic imbalances and the role of the State in the Economy," in which the evaluation criterion is "to reflect on the impact of growth and cyclical crises on the Economy and their effects on the quality of life of people, the environment and the distribution of wealth at a local and global level," with four different evaluable learning standards related to the environment. For the subject of business economics in the second year of Bachillerato there are issues related to sustainability in three of the seven blocks into which the subject is divided: in block 1 are issues related to the company in which the assessment criterion is "to identify the main features of the sector in which the company develops its activity and the possible social and environmental implications"; in block 2 are issues in which a learning standard is "to describe the characteristics and development strategies of the multinational company and to assess the importance of social and environmental responsibility"; and in block 5 are issues that deal with the commercial function of the company with the assessable learning standard "to interpret and assess marketing strategies, incorporating in that assessment considerations of an ethical, social and environmental nature."

However, regardless of whether these issues are dealt with in greater or lesser depth, it is a fact and a reality that a change of paradigm is taking place in the way education is conceived. Attempts are being made to establish some minimum content to be dealt with that allows the student to know the social, economic and, environmental impacts of the economic decisions that are made, and how each of us can contribute to reducing that negative impact.

\subsection{Gender and Sustainability}

Over the years, several studies have shown that the concern about contributing to the development of sustainable practices varies according to gender [46]. Women attach greater value to the principles 
and values related to sustainable development [47]. In this sense, the authors of [48] showed that women show stronger pro-environmental attitudes and behaviors than men. They tend to be more sensitive to the environment, although sometimes the statistically significant effects are quite low $[49,50]$.

In the business sphere, these gender differences are also present. There is a positive relationship between the proportion of female directors and socially responsible companies [51,52]. The gender of the company's top executive affects the company's Corporate Social Responsibility performance [53] and, in addition, the presence of women on the board of directors is associated with improved sustainability reporting $[54,55]$.

In addition, women tend to conserve and preserve nature more [56-58]. They score higher on factors related to naturalism and ecocentrism with a nature-centered value system [49]. These differences may be due to the model of basic human values [59], where the values of self-transcendence and contribution to public welfare as citizens represent more feminine values [60].

Authors of [61] investigated attitudes of sustainability among students and found that there was a difference in gender, especially in issues related to solidarity and equity, where women stand out over men. The explanation for gender differences may be that students have been socialized into identities [62-65]. The social construction of gender begins in the early years and is a process in which parents and teachers tend to treat boys and girls differently.

\section{Materials and Method}

In general, schools are trying to adapt to include sustainability in their content, but is this enough? Do students come to understand what the concept of sustainability means, do they really know what it means to be sustainable and the implications it has, do they behave in a sustainable way?

In order to answer all these questions, a survey was carried out among students in the subject of economics in secondary school, which comprised a comprehensive approach to SD. It covered ecological, social, cultural, economic, and political aspects, etc., covering the three dimensions of sustainability: social, economic, and environmental [66,67].

The questionnaire was an adaptation of previous works that analyzed the perceptions of the subjects regarding the natural environment [19-21], focused on primary and secondary students (grades 6-12). They collected items related to the concepts in the United Nations Educational, Scientific and Cultural Organization such as the knowledge, attitudes, and relative behavior towards SD of the students.

From the revision of these works a group of questions were elaborated, which were revised by three experts to increase the validity of the obtained scale. This questionnaire was completed with a focus group of 10 students who were studying any economic subject, which allowed reformulating some of the items and elaborating the final questionnaire.

The survey consisted of 30 questions grouped into three blocks (Table 1). A first block determined the degree of knowledge about sustainability: what they really understand by sustainable development and with what concepts they associate it. The second block dealt with the attitude they believe should be adopted to achieve a more sustainable world. The third block determined how they actually behave when faced with sustainability issues. To find out their degree of agreement or disagreement with the issues raised, each question answered a Likert model with five grades, from 1-strongly disagree to 5-totally agree. 
Table 1. Items to measure sustainable development (SD) knowledge, attitude, and behavior.

\begin{tabular}{|c|c|}
\hline KNOWLEDGE & $\begin{array}{l}\text { K1: Reduction of water consumption is necessary for SD. } \\
\text { K2: Nature conservation is necessary for SD. } \\
\text { K3: SD demands that we humans reduce all types of waste. } \\
\text { K4: SD requires a shift towards renewable natural resources } \\
\text { K5: Promoting gender equality is central to SD. } \\
\text { K6: Respect for human rights is necessary for SD. } \\
\text { K7: Improving people's opportunities to lead long and healthy lives contributes to SD. } \\
\text { K8: Respect for other cultures is necessary for SD. } \\
\text { K9: To achieve SD, all people must have access to a good education. } \\
\text { K10: SD requires companies to act responsibly towards their employees, customers, and suppliers. } \\
\text { K11: Global poverty eradication is necessary for SD. }\end{array}$ \\
\hline ATTITUDE & $\begin{array}{l}\text { A1: Governments' economic policies must increase sustainable production, even if it means spending more money. } \\
\text { A2: Women and men around the world should have equal opportunities for education and employment. } \\
\text { A3: Companies should have a responsibility to reduce the use of packaging and disposable items. } \\
\text { A4: Reducing world poverty and hunger is more important than increasing the economic welfare of industrialized countries. } \\
\text { A5: The government should make all its decisions on the basis of the SD. } \\
\text { A6: It is important that people in society exercise their democratic rights and get involved in important issues. } \\
\text { A7: Everyone should have the opportunity to acquire the knowledge and values necessary for sustainable living. } \\
\text { A8: Contact between cultures is necessary and enriching. } \\
\text { A9: We need stricter laws and regulations to protect the environment. } \\
\text { A10: Those of us living now must ensure that people in the future enjoy the same quality of life as we do today. } \\
\text { A11: It is important to take action against problems that have to do with climate change. }\end{array}$ \\
\hline BEHAVIOR & $\begin{array}{l}\text { B1: I never waste water. } \\
\text { B2: I recycle as much as I can. } \\
\text { B3: I have changed my personal lifestyle to reduce waste (for example, throwing away less food or not wasting materials). } \\
\text { B4: I pick up trash when I see it in the field or in public places. } \\
\text { B5: I do things that help people in need. } \\
\text { B6: When I chat, send text messages, etc., I always treat others with the same respect as when I do it in person. } \\
\text { B7: I treat everyone with the same respect, even if they have a different cultural origin than mine. } \\
\text { B8: I show the same respect to men and women, boys and girls. } \\
\text { B9: I encourage the purchase of fair trade products. } \\
\text { B10: I encourage consumption of products not made by children, cheap labour. }\end{array}$ \\
\hline
\end{tabular}

The KMO and Bartlett tests allowed verification of the suitability of the data for exploratory factor analysis $[68,69]$. This analysis was performed on each block with varimax rotation, to determine the links between the observed variables and the resulting factors [25,70]. Kaiser's criterion [71] was used to determine the number of latent factors in each block.

From the matrix of the rotated components, for each analysis carried out, the sustainability factors of each block were identified and labelled, and the three dimensions that make up SD appeared: environmental, social, and economic. These factors were ordered according to the amount of information they provided from highest to lowest, that is, according to the percentage of variance explained by each one of them. The consistency of the factors thus obtained was analyzed using the Cronbach's alpha value. The corresponding scales were determined from these factors as an average of the item scores that determined each factor. With these scales, together with the weighting associated with each of them (weighting given by the factor analysis), a global indicator was calculated for each of the survey blocks.

From these new scores, a global indicator was obtained for students' knowledge of SD, another one for attitude towards SD, and another one for sustainable behavior. This global indicator was calculated as the weighted sum of the new scores, with the weighting being the percentage explained by each factor that determined those scores. The expression of the indicator is given by the expression (1):

$$
I_{i}=\sum_{j=1}^{k} \frac{w_{j}}{\sum_{j=1}^{k} w_{j}} F_{i j},
$$

where $F_{i j}$ is the score on factor $j$ for individual $i, k$ is the number of factors, and $w_{j}$ is the percentage of variance explained by factor $j$ once rotated.

These indicators vary between 1 and 5 . The greater the value, the stronger will be the knowledge, attitude, and commitment to sustainable development on the part of individuals. The scores given by women and men to the three blocks of the questionnaire were also analyzed and the indicators were calculated according to gender. 
For a more precise study to ascertain the statistical significance of the differences, the means of the scores in each of the items of the questionnaire were subjected to the student $t$-test for independent samples, a technique that provided the bilateral significance obtained from the comparison of the means of the data. The student's perception in each of the blocks was analyzed by studying whether there were significant differences by sex. Furthermore, the size of the effect (measured by eta square) of the sex factor was calculated to measure how much variance in the dependent quantitative variable was the result of the influence of the independent qualitative variable, in other words, how much did the independent variable (factor) affect the dependent variable. A square eta around 0.01 is usually considered to cause a small effect, around 0.06 a medium effect, and above 0.14 a large effect.

\section{Result}

After meeting with the different coordinators of Bachillerato and explaining the objective of the research, the questionnaire was sent to all the educative centers of the northern area of the Region of Murcia (Spain) at the beginning of course 2019-2020. The socioeconomic level of the families that lived in this area was homogeneous, considered as upper-middle level.

The target population of the survey was approximately 1000 students. The sampling size was calculated with $95 \%$ confidence, an expected proportion of $50 \%$ and an error of $2 \%$. The response rate was high, approximately $80 \%$, with the final sample of 572 high school students. Of these, $304(53.1 \%)$ were girls and 268 (46.9\%) boys. Their ages varied between 15 and 18 years, with $55.2 \%$ being 17 years old and $31.5 \% 16$ years old.

All the students declared to know what sustainable development was, high school being their main source of information, followed by very similar percentages of television, internet, and social networks (Table 2). This shows the importance of teaching sustainability issues at the school, as it was the main source of information. On the opposite end was the family, as only $20.5 \%$ heard of sustainability in their home.

Table 2. Where have you heard about sustainable development?

\begin{tabular}{cccccccc}
\hline Source & $\begin{array}{c}\text { High } \\
\text { School }\end{array}$ & Television & Internet & $\begin{array}{c}\text { Social } \\
\text { Networks }\end{array}$ & Home & Friends & Press \\
\hline Percentage & 78.7 & 53.2 & 52.8 & 50.4 & 20.5 & 20.5 & 18.9 \\
\hline
\end{tabular}

After analyzing the internal reliability of the survey for each of the blocks, Cronbach's alphas of $0.831,0.898$, and 0.739 were obtained, respectively, indicating a high internal consistency between the variables of each block.

Table 3 shows the mean and the standard deviation of each of the items in the block referring to students' knowledge of SD. Those statements that related the environmental dimension, such as the need to conserve the environment in order to contribute to sustainable development, or that sustainable development requires a shift towards renewable natural resources, were widely supported by the vast majority of students. This proves that they are aware of the importance of preserving the environment in order to contribute to a more sustainable world. If we analyzed according to the sex of the students, it was seen that the mean was a little higher in the case of women, especially in variables K1—the reduction of the water use necessary for $\mathrm{SD}$-and $\mathrm{K} 4-\mathrm{SD}$ requires a change towards the renewables natural resources (whose differences were statistically significant).

In the items related to the social dimension ( $\mathrm{K} 5$ to $\mathrm{K} 8$ ) the mean was high, but lower than in the rest of the variables that formed the set of items, obtaining a higher score in the case of being a woman. On the other hand, when asked about other concepts included in the economic dimension of sustainability, the score was higher if it was male, although the mean of the two groups was around 4. These differences were not very relevant, the only significant one, statistically, being in variable K11 - the eradication of poverty in the world is necessary for SD. Regarding the size of the effect, 
measured by eta-squared coefficient, it was observed that the effect of the sex factor had an average importance in all variables that resulted statistically significant.

Table 3. Mean and standard deviation (SD) of items on knowledge of sustainable development by sex.

\begin{tabular}{ccccccccc}
\hline & \multicolumn{2}{c}{ Total } & \multicolumn{2}{c}{ Man } & \multicolumn{2}{c}{ Woman } & t-Student & Effect \\
& Mean & SD & Mean & SD & Mean & SD & $p$-Value & Size \\
\hline K1 & 3.96 & 1.04 & 3.87 & 1.12 & 4.04 & 0.96 & 0.046 & 0.06 \\
K2 & 4.55 & 0.80 & 4.52 & 0.85 & 4.57 & 0.77 & 0.459 & - \\
K3 & 3.94 & 1.05 & 3.90 & 1.11 & 3.98 & 1.00 & 0.382 & - \\
K4 & 4.08 & 1.02 & 3.98 & 1.06 & 4.17 & 0.97 & 0.023 & 0.07 \\
K5 & 3.64 & 1.25 & 3.50 & 1.22 & 3.77 & 1.27 & 0.010 & 0.07 \\
K6 & 3.87 & 1.16 & 3.73 & 1.19 & 3.99 & 1.12 & 0.007 & 0.08 \\
K7 & 3.68 & 1.04 & 3.63 & 0.95 & 3.73 & 1.11 & 0.235 & - \\
K8 & 3.59 & 1.18 & 3.49 & 1.20 & 3.68 & 1.15 & 0.044 & 0.06 \\
K9 & 3.94 & 1.05 & 4.01 & 0.99 & 3.88 & 1.10 & 0.131 & - \\
K10 & 3.99 & 1.07 & 3.99 & 1.08 & 3.98 & 1.06 & 0.891 & - \\
K11 & 3.90 & 0.98 & 4.00 & 0.94 & 3.80 & 1.02 & 0.017 & 0.07 \\
\hline
\end{tabular}

Note: The definitions of the knowledge items can be consulted in Table 1.

This shows that students are aware that the planet is becoming less and less sustainable and that measures must be put in place to eradicate this problem, but they think that the concept of sustainability affects the environment more, without considering other areas.

On the other hand, when we asked them about the attitude and measures that should be implemented to generate a more sustainable world (the results are in Table 4) the lowest scores were in terms of whether they believed that government should make all its decisions on the basis of sustainable development (A5), or whether government economic policies should increase sustainable production (A1), even if it means spending more money, many were not entirely satisfied. Only $27 \%$ of respondents agreed strongly with the first statement and 37\% agreed with the second. This indicates that economics students, despite being aware that there is a problem that affects the planet globally, think that decisions should not be made based on the impact (sustainable or not) that they may have on the planet.

Table 4. Mean and standard deviation (SD) of items on attitude towards sustainable development by sex.

\begin{tabular}{lcccccccc}
\hline & \multicolumn{2}{c}{ Total } & \multicolumn{2}{c}{ Man } & \multicolumn{2}{c}{ Woman } & \multicolumn{2}{c}{ t-Student } \\
$p$-Value & $\begin{array}{c}\text { Effect } \\
\text { Size }\end{array}$ \\
& Mean & SD & Mean & SD & Size & SD & - \\
A1 & 4.01 & 0.98 & 3.96 & 0.97 & 4.07 & 0.98 & 0.177 & -10 \\
A2 & 4.45 & 0.97 & 4.28 & 1.07 & 4.61 & 0.85 & 0.000 & 0.10 \\
A3 & 4.12 & 1.00 & 4.04 & 1.00 & 4.20 & 0.98 & 0.055 & 0.10 \\
A4 & 4.06 & 1.08 & 3.95 & 1.12 & 4.15 & 1.05 & 0.025 & 0.07 \\
A5 & 4.02 & 0.80 & 4.02 & 0.71 & 4.01 & 0.88 & 0.891 & - \\
A6 & 4.06 & 1.01 & 4.00 & 0.98 & 4.11 & 1.03 & 0.212 & - \\
A7 & 4.39 & 0.99 & 4.32 & 1.00 & 4.45 & 0.98 & 0.109 & - \\
A8 & 4.09 & 0.98 & 3.90 & 1.00 & 4.25 & 0.94 & 0.000 & 0.11 \\
A9 & 4.28 & 1.01 & 4.10 & 1.05 & 4.43 & 0.95 & 0.000 & 0.10 \\
A10 & 4.24 & 0.98 & 4.15 & 0.94 & 4.32 & 1.01 & 0.036 & 0.06 \\
A11 & 4.41 & 0.94 & 4.28 & 0.91 & 4.53 & 0.95 & 0.001 & 0.08 \\
\hline
\end{tabular}

Note: The definitions of the attitude items can be consulted in Table 1.

In this block on attitude, the scores given by students were above 4 on all items. The highest mean was reached in the variables "Women and men around the world should have the same opportunities for education and employment" (A2), and "I think it is important to take action against problems related to climate change" (A11). By sex there were differences between the scores assigned to the different 
items, with women's scores always being higher. These differences were significant in seven of the 11 variables, suggesting that women have a greater attitude towards sustainability. The statistically significant variables of our study presented an average effect on the variable of the gender of the student.

In terms of their behavior towards sustainability (Table 5), the majority claimed to treat everyone with the same respect, regardless of their cultural background, just as they respected men and women equally, although when they chat, the number of people who claimed to treat everyone with the same respect decreased. However, they were not so predisposed to collecting garbage found in public places, nor did they recycle as much as they could. Moreover, they did not usually do things to help those most in need, and most did not consider whether the products were made by children or cheap labor.

Table 5. Mean and standard deviation (SD) of the items on behavior by sex.

\begin{tabular}{|c|c|c|c|c|c|c|c|c|}
\hline & \multicolumn{2}{|c|}{ Total } & \multicolumn{2}{|c|}{ Man } & \multicolumn{2}{|c|}{ Woman } & \multirow{2}{*}{$\begin{array}{c}\mathrm{t} \text {-Student } \\
p \text {-Value }\end{array}$} & \multirow{2}{*}{$\begin{array}{l}\text { Effect } \\
\text { Size }\end{array}$} \\
\hline & Mean & SD & Mean & SD & Mean & SD & & \\
\hline B1 & 3.31 & 1.00 & 3.29 & 0.96 & 3.32 & 1.03 & 0.709 & - \\
\hline B2 & 3.55 & 1.02 & 3.46 & 0.95 & 3.63 & 1.07 & 0.047 & 0.06 \\
\hline B3 & 3.62 & 1.10 & 3.57 & 1.08 & 3.66 & 1.11 & 0.329 & - \\
\hline B4 & 3.24 & 0.93 & 3.25 & 0.89 & 3.24 & 0.96 & 0.971 & - \\
\hline B5 & 3.69 & 0.80 & 3.61 & 0.75 & 3.75 & 0.83 & 0.039 & 0.06 \\
\hline B6 & 4.13 & 0.89 & 3.93 & 0.87 & 4.30 & 0.88 & 0.000 & 0.15 \\
\hline B7 & 4.43 & 0.89 & 4.25 & 0.89 & 4.60 & 0.86 & 0.000 & 0.14 \\
\hline B8 & 4.49 & 0.87 & 4.29 & 0.91 & 4.66 & 0.80 & 0.000 & 0.14 \\
\hline B9 & 4.07 & 0.66 & 4.12 & 0.68 & 4.02 & 0.64 & 0.073 & 0.02 \\
\hline B10 & 2.80 & 1.31 & 2.91 & 1.18 & 2.71 & 1.41 & 0.069 & 0.06 \\
\hline
\end{tabular}

Note: The definitions of the behavior items can be consulted in Table 1.

The mean of the variables in this block were above 4 on the items: B6, B7, B8, and B9. However, the variable "I encourage consumption of products that are not made by children, cheap labour" (B10), had a very low mean, probably because this concept did not fit sufficiently into them. Analyzing the table by sex, it was again women who obtained the higher mean, the difference being statistically significant above $95 \%$ in items B2, B5, B6, B7, and B8, and at 90\% in the last two variables. The size of the effect (measured by the factor eta square) was high for the variables that alluded to different aspects dealing with the respect towards other people: B6, B7, and B8. However, in the variable B9, which had a significance statistic lower than the others, the effect of the sex factor was low.

\section{Exploratory Factor Analysis}

For each of the blocks a factorial analysis was carried out to try to summarize all the available information into a set of factors with a clear interpretation of the phenomenon being studied. Moreover, the importance that each one of these factors had within the group of variables was obtained, represented by the variance explained by the same, which was used to calculate the global indicator.

In the first block of questions referring to the knowledge that the students had about SD, a new structure with three factors was obtained after a varimax rotation that explained $62.7 \%$ of the variance (Table 6) and with a KMO coefficient of 0.831 , which indicated that the analysis carried out was correct. 
Table 6. Factorial analysis of knowledge items on sustainable development.

\begin{tabular}{c|cccc}
\hline Dimension & Variables & F1 & F2 & F3 \\
\hline \multirow{5}{*}{ Environmental } & K3 & 0.813 & & \\
& K1 & 0.779 & & \\
& K4 & 0.750 & & \\
& K2 & 0.688 & & \\
Social & K5 & & 0.855 & \\
& K6 & & 0.751 & 0.731 \\
& K8 & & 0.616 & 0.751 \\
& K7 & & & 0.617 \\
\hline \multirow{3}{*}{ Economic } & K11 & & & $17.56 \%$ \\
\hline & K10 & & & \\
& K9 & & & \\
& Weight $\left(\mathrm{w}_{\mathrm{i}}\right)$ & $22.71 \%$ & $22.40 \%$ & \\
\hline
\end{tabular}

Note: The definitions of the behavior items can be consulted in Table 1.

The first factor, associated with the environmental component of sustainability, related the variables: "The reduction of water consumption is necessary for SD" (K1), "Nature conservation is necessary for SD" (K2), "SD demands that we humans reduce all types of waste" (K3), and "SD requires a change towards renewable natural resources" (K4). It explained $22.71 \%$ of the variability of the knowledge block and had a good reliability of 0.792 , as a subscale of four variables $\left(\mathrm{K}_{\mathrm{F} 1}\right)$.

The variables "Promoting equality between men and women is fundamental for SD" (K5), "Respect for human rights is necessary for SD" (K6), "Improving people's opportunities for a long and healthy life contributes to SD" (K7), and "Respect for other cultures is necessary for SD" (K8), relating to the social component of sustainability, determined the second factor. This subscale, $\mathrm{K}_{\mathrm{F} 2}$, had a good reliability of 0.772 and explained $22.40 \%$ of the variance.

The third factor was formed by the variables: "To achieve SD everyone needs to have access to a good education" (K9), "SD requires companies to act responsibly towards their employees, customers and suppliers" (K10), and "Global poverty eradication is necessary for SD" (K11). A subscale, $\mathrm{K}_{\mathrm{F} 3 \text {, }}$ associated with the economic component of sustainability, was formed. Its reliability (0.723) was acceptable and explained $17.56 \%$ of the variance variability.

The factorial analysis carried out on the block of questions that reflected the attitude that students believe should be adopted to achieve a more sustainable world, obtained two factors that explained about $61 \%$ of the variability of the variance (Table 7 ) with a high KMO of 0.921.

Table 7. Factorial analysis of attitude items towards sustainable development.

\begin{tabular}{c|ccc}
\hline Dimension & Variables & F1 & F2 \\
\hline \multirow{5}{*}{ Social } & A5 & 0.797 & \\
Economic & A10 & 0.777 & \\
& A2 & 0.761 & \\
& A7 & 0.721 & \\
& A4 & 0.688 & \\
& A1 & 0.686 & \\
& A6 & 0.662 & \\
& A8 & 0.638 & \\
Environmental & A3 & & 0.826 \\
& A11 & & 0.825 \\
& A9 & & 0.677 \\
\hline & Weight $\left(\mathrm{w}_{\mathrm{i}}\right)$ & $39.63 \%$ & $21.26 \%$ \\
\hline
\end{tabular}

Note: The definitions of the behavior items can be consulted in Table 1. 
The first factor included the eight variables related to the social and economic dimensions of sustainability, corresponding to the items from A1 to A8 (Table 1). This factor had, as a subscale of eight variables $\left(\mathrm{A}_{\mathrm{F} 1}\right)$, a very good reliability of 0.9 , and explained $39.63 \%$ of the variance.

The second factor obtained in the factor analysis included three variables all related to the environmental dimension of sustainability. These were: "I believe we need stricter laws and regulations to protect the environment " (A4), "I believe that those of us living now must ensure that people in the future enjoy the same quality of life as we do today" (A10), and "I believe that it is important to take action against the problems associated with climate change" (A11). The reliability of the scale created, $\mathrm{A}_{\mathrm{F} 2}$, was acceptable, 0.762 , and explained $21.26 \%$ of the variance.

The particular behavior of students towards sustainability was the basis of the third block of our survey. Through factor analysis, we extracted three differentiated factors (Table 8) that told us about the three dimensions of sustainability. The variance explained, in this case, was $66.27 \%$ with a KMO index of 0.83 .

Table 8. Factorial analysis of behavior items on sustainable development.

\begin{tabular}{|c|c|c|c|c|}
\hline Dimension & Variables & F1 & $\overline{F 2}$ & F3 \\
\hline \multirow{4}{*}{ Environmental } & B3 & 0.858 & & \\
\hline & B4 & 0.832 & & \\
\hline & B1 & 0.822 & & \\
\hline & B2 & 0.804 & & \\
\hline \multirow{4}{*}{ Social } & B7 & & 0.856 & \\
\hline & B8 & & 0.818 & \\
\hline & B6 & & 0.798 & \\
\hline & B5 & & 0.666 & \\
\hline \multirow{3}{*}{ Economic } & B9 & & & 0.791 \\
\hline & B10 & & & 0.650 \\
\hline & Weight $\left(\mathrm{w}_{\mathrm{i}}\right)$ & $28.97 \%$ & $25.87 \%$ & $11.49 \%$ \\
\hline
\end{tabular}

Note: The definitions of the behavior items can be consulted in Table 1.

The first factor, related to the environmental dimension, explained $28.97 \%$ of the variability of the variance. It was formed by the variables: "I never waste water" (B1), "I recycle as much as I can" (B2), "I have changed my personal lifestyle to reduce waste" (B3), and "I pick up trash when I see it in the field or in public places" (B4). The reliability achieved with this subscale, $\mathrm{B}_{\mathrm{F} 1}$, was good at 0.8 .

The social dimension appeared in the second factor. It was made up of the variables: "I do things that help the neediest people" (B5), "When I chat, send text messages, etc., I always treat others with the same respect as when I do it in person" (B6), "I treat everyone with the same respect, even if they have a different cultural background from mine" (B7), "I show the same respect to men and women, boys and girls" (B8). The reliability of this three-question subscale, $\mathrm{B}_{\mathrm{F} 2}$, was 0.772 and the variance explained by the factor was $25.87 \%$.

In the last factor, the variables related to the economic sphere appeared: "I encourage the purchase of fair trade products" (B9) and "I encourage the consumption of products that are not made by children, cheap labour" (B10). The variance explained by this component was $11.44 \%$ and the reliability of the subscale, $\mathrm{B}_{\mathrm{F} 3}$, was 0.723 .

From the subscales obtained from each of the blocks analyzed, an indicator of knowledge $\left(\mathrm{I}_{\mathrm{K}}\right)$, another of attitude $\left(\mathrm{I}_{\mathrm{A}}\right)$, and another of behavior $\left(\mathrm{I}_{\mathrm{B}}\right)$ towards $\mathrm{SD}$ of each student was calculated. The expression of each one of them, according to Equation 1, is reflected in Equations 2, 3, and 4 , respectively.

$$
\begin{aligned}
& I_{K}= \frac{22.77 \cdot K_{F 1}+22.40 \cdot K_{F 2}+17.56 \cdot K_{F 3}}{22.77+22.40+17.56}, \\
& I_{A}=\frac{39.63 \cdot A_{F 1}+21.26 \cdot A_{F 2}}{39.63+21.26} \\
& I_{B}=\frac{28.97 \cdot B_{F 1}+25.87 \cdot B_{F 2}+11.49 \cdot B_{F 3}}{28.97+25.87+11.49},
\end{aligned}
$$


Each indicator is a weighted mean of the subscales obtained, weighted by the percentage of variance that explains each one of them in the corresponding factor analysis.

Table 9 shows the mean and standard deviation of the partial and global scales of each of the three parts that made up the survey. In the subscales of knowledge, the one with the highest mean was the one referring to the environmental component, an aspect commented on previously, and also the one with the lowest dispersion. Distinguishing by sex, the mean was higher among women, except in the component referring to the social sphere of knowledge. For those with an attitude towards sustainability, the global means were the same; however, when distinguishing by sex, men gave a higher score to the first one and women to the environmental dimension, with statistically significant differences between the two sexes. When analyzing the subscales referring to student behavior towards sustainability, a clear difference in means was observed between them. Although the social scale had a high mean of 4.35 , the economic scale reached only 2.37 points, within the scale used from 1 to 5 . The significant differences were only found on the second subscale, where the mean of women was $9 \%$ superior to the mean of men. The sizes of the effect of the sex factor were stronger in attitude and behavior.

Table 9. Mean and standard deviation (SD) of the partial and global scales according to sex.

\begin{tabular}{cccccccccc}
\hline & \multicolumn{2}{c}{ Total } & \multicolumn{2}{c}{ Man } & \multicolumn{2}{c}{ Woman } & t-Student & Effect \\
Mean & SD & Mean & SD & Mean & SD & $p$-Value & Size \\
\hline \multirow{6}{*}{ Partial } & $\mathbf{K}_{\mathbf{F 1}}$ & 4.13 & 0.77 & 4.07 & 0.83 & 4.19 & 0.71 & 0.056 & 0.02 \\
& $\mathbf{K}_{\mathbf{F} 2}$ & 3.70 & 0.89 & 3.59 & 0.88 & 3.79 & 0.90 & 0.005 & 0.09 \\
& $\mathbf{K}_{\mathbf{F} 3}$ & 3.94 & 0.83 & 4.00 & 0.79 & 3.89 & 0.87 & 0.101 & - \\
& $\mathbf{A}_{\mathbf{F} 1}$ & 4.19 & 0.73 & 4.11 & 0.70 & 4.27 & 0.74 & 0.010 & 0.03 \\
& $\mathbf{A}_{\mathbf{F} 2}$ & 4.20 & 0.83 & 4.04 & 0.88 & 4.34 & 0.77 & 0.000 & 0.13 \\
& $\mathbf{B}_{\mathbf{F} 1}$ & 3.43 & 0.85 & 3.39 & 0.82 & 3.47 & 0.88 & 0.316 & - \\
& $\mathbf{B}_{\mathbf{F} 2}$ & 4.35 & 0.76 & 4.16 & 0.72 & 4.52 & 0.75 & 0.000 & 0.14 \\
& $\mathbf{B}_{\mathbf{F} 3}$ & 2.37 & 0.71 & 2.40 & 0.64 & 2.35 & 0.76 & 0.397 & - \\
\hline \multirow{5}{*}{ Global } & $\mathbf{I}_{\mathbf{K}}$ & 3.92 & 0.65 & 3.88 & 0.63 & 3.96 & 0.66 & 0.108 & - \\
& $\mathbf{I}_{\mathbf{A}}$ & 4.19 & 0.69 & 4.09 & 0.67 & 4.29 & 0.69 & 0.000 & 0.14 \\
& $\mathbf{I}_{\mathbf{B}}$ & 3.61 & 0.55 & 3.52 & 0.49 & 3.68 & 0.58 & 0.000 & 0.14 \\
\hline
\end{tabular}

\section{Discussions and Conclusions}

Today, the population is aware of environmental problems such as climate change and environmental degradation, although many are not aware of their extent. These problems must be remedied, and practices that lead to the achievement of sustainable development should be implemented. That is why education and the content provided have a key role to play.

In this work, the knowledge, attitude, and behavior towards SD were analyzed through a survey of young people who studied economics subjects in high school. They affirmed, for the most part, that they acquired information on the problems associated with sustainability through their educational center, which shows the importance of teaching this subject.

Young people, in general, were aware of the need to preserve the environment to ensure the future of the planet, although women valued more than men the aspects related to the reduction of water consumption and the use of renewable natural resources. Students were aware of the problems involved in SD, but they thought that this problem mainly affected the environment. Although the social sphere was important for girls and the economic sphere for boys, both remained in the background, with the environmental part being more relevant.

When dealing with the attitude towards SD, economic well-being took precedence over social and environmental impacts. Most thought that government should not make its decisions based on SD and that economic policies should not be aimed at increasing sustainable production. In spite of this, women showed a greater attitude towards sustainability, coinciding with the results obtained by $[29,30]$. 
When asked about their behavior towards SD they were very committed to this issue, claiming to treat everyone, regardless of culture or gender, with a lot of respect. They declared to care for and protect the environment, but when it came to recycling or picking up trash in public places, their willingness to do so was not as high. It was very striking how low they scored on the fact that the products we consume are made by children or cheap labor. As in the previous aspects, women showed more favorable behavior towards sustainability than their partners in all the questions asked, coinciding with the results obtained by [61].

Through a factorial analysis of each of the three differentiated blocks of the survey, different subscales were obtained. This allowed the calculation of partial sustainability indices for students' knowledge, attitude, and behavior towards sustainability. Both in knowledge and behavior the subscales found were associated with the environmental, social, and economic dimensions of sustainability, while in attitude the social and economic spheres were not differentiated. The good attitude towards SD was noteworthy, in the same line as the result reached by [21], with a high knowledge of it and a low valuation in the behavior towards the economic dimension. Women always showed a stronger attitude and behavior than men towards environmental aspects, coinciding with the results of $[48,49]$ and [23].

These partial indicators were used to construct global indicators for each of the aspects analyzed. The assessment was superior in the attitude towards sustainability. There were statistically significant differences by sex, the case of girls always being superior.

All the results obtained from this investigation lead to the idea that it is necessary, in education, to emphasize the importance of understanding the concept of sustainability in its broadest sense, not only from the environmental sphere. Furthermore, it is important to relate economic content to sustainable development, and to study the impacts that certain economic decisions will have on the planet. It is necessary to work together with other subjects so that the student can see that in each field he or she can contribute to generating a more sustainable world. In the economic area, the importance of making economic decisions that are appropriate to the environment must be stressed. The student must learn that not only are profit and economic profitability important, but that, in the long term, this greater short-term benefit can generate great losses for everyone, both for him/her as an economist and/or businessman, and for all of society and future generations.

The student is instructed and requested to act, but making appropriate and profitable economic decisions should be stressed as much as the importance of making those decisions in a consistent and fully sustainable manner. Many of them intend to dedicate themselves to the business world in the future, where they will have to make important decisions and evaluate the different strategies they will implement in the business. They need to understand that economic benefit should not be put before anything else, and that the impact that their decisions have on the environment should not be put aside.

It is important to make changes in economics curricula and textbooks to achieve sustainability. It is not a matter of including only some concepts related to it in the curricula, but it is necessary to identify and make those elements visible in order to create awareness within the educational community. For students, making the most efficient decision can be considered more important, based on the previously studied economic theories, while the social and environmental impacts that it can have upon society remain in the background. For most of them, the first thing is economy, not looking beyond. Maybe herein lies another problem of education.

Students perform actions without realizing that they contribute to SD, as for them sustainability implies only the care and protection of the environment and nature; this is the reason why it is very important to educate more on sustainability. It is clear that environmental education will have to include an active learning as well as a deep and critical reflection, and should not be reduced to merely transmitting theoretical knowledge about climate change, the ecological crisis, or the existence of limited resources. Here, too, teachers will play an important role, since their degree of involvement and participation in sustainable practices will be important. 
As a conclusion to this study, it can be inferred that the attitude and knowledge of young people towards sustainability is high, but when it comes to their behavior, it is affected by concerns more about welfare than about commitment to SD. It is the task of teachers to influence this aspect in order to inculcate a spirit more committed to the future of our planet.

Currently, the behavior of other groups of students from the same educative centers is being analyzed, with the difference being that they do not study economic subjects. With this we can contrast if significant differences exist in knowledge, attitude, and behavior towards SD according to the subjects studied. Analyzing the level of studies of the parents may also influence this issue.

Author Contributions: Methodology, J.C.-F., U.F.-M. and M.L.-L.; conceptualization, J.C.-F., U.F.-M. and M.L.-L; investigation, J.C.-F.; validation, J.C.-F., U.F.-M. and M.L.-L.,,; formal analysis, U.F.-M. and M.L.-L; supervision, J.C.-F., U.F.-M. and M.L.-L.; review and editing, J.C.-F., U.F.-M. and M.L.-L.. All authors have read and agreed to the published version of the manuscript.

Funding: This research received no external funding.

Conflicts of Interest: The authors declare no conflict of interest.

\section{References}

1. World Commission on Environment and Development. Our Common Future; The Brundtland Report; Oxford University Press: Oxford, UK, 1987; Available online: https://sustainabledevelopment.un.org/content/ documents/5987our-common-future.pdf (accessed on 7 April 2020).

2. UNESCO. El Decenio de las Naciones Unidas para la EDS. 2014. Available online: https://es.unesco.org/ themes/educacion-desarrollo-sostenible/comprender-EDS/decenio-onu (accessed on 7 April 2020).

3. Stevenson, R. Researching tensions and pretensions in environmental/sustainability education policies: From critical to civically engaged policy scholarship. In International Handbook of Research on Environmental Education; Stevenson, R., Brody, M., Dillon, J., Wals, A., Eds.; Routledge Publishers: New York, NY, USA, 2013; pp. 147-155.

4. Robottom, I. Changing discourses in EE/EDS: A role for professional self-development. In International Handbook on Research on Environmental Education; Stevenson, R.B., Brody, M., Dillon, J., Wals, A.E.J., Eds.; AERA: New York, NY, USA; Routledge: London, UK, 2013; pp. 156-162.

5. Azeiteiro, U.M.; Bacelar-Nicolau, P.; Caetano, F.J.P.; Caeiro, S. Education for sustainable development through e-learning in higher education: Experiences from Portugal. J. Clean. Prod. 2015, 106, 308-319. [CrossRef]

6. Murga-Menoyo, M.A. Competencias para el desarrollo sostenible: Las capacidades, actitudes y valores meta de la educación en el marco de la agenda global post-2015. Foro Educ. 2015, 13, 55-83. [CrossRef]

7. Lozano, R.; Lukman, R.; Lozano, F.J; Huisingh, D.; Lambrechts, W. Declarations for sustainability in higher education: Becoming better leaders, through addressing the university system. J. Clean. Prod. 2013, 48, 10-19. [CrossRef]

8. Gonzalo, M.V.; Sobrino, C.M.R.; Benítez, S.L.; Coronado, M.A. Revisión sistemática sobre competencias en desarrollo sostenible en educación superior. Desarrollo sostenible y educación superior en un mundo global. Rev. Iberoam. Educ. 2017, 73, 85-108.

9. Mindt, L.; Rieckmann, M. Developing competencies for sustainability-driven entrepeneurship in higher education: A literature review of teaching and learning methods. Teoría Educ. Rev. Interuniv. 2017, 29, 129-159. [CrossRef]

10. Murga-Menoyo, M.A. Universidades en transición. Hacia una transformación institucional orientada al logro de la sostenibilidad. Rev. Iberoam. Educ. 2017, 73, 61-84. [CrossRef]

11. UNESCO. A Decade of Progress on Education for Sustainable Development; Reflections from the UNESCO Chairs Programme: Paris, France, 2017.

12. UNESCO. Education for Sustainable Development Goals; Learning objectives; UNESCO: Paris, France, 2017.

13. Torres, R.; Vieira, R.M.; Rodrigues, A.V.; Sá, P.; Moreira, G. Education for sustainable development: An exploratory study in a Portuguese University. Int. J. Sustain. High. Educ. 2017, 18, 956-970. [CrossRef]

14. Aleixo, A.M.; Leal, S.; Azeiteiro, U.M. Conceptualizations of sustainability in Portuguese higher education: Roles, barriers and challenges toward sustainability. J. Clean. Prod. 2018, 172, 1664-1673. [CrossRef] 
15. Ortega-Sánchez, M.; Moñino, A.; Bergillos, R.J.; Magaña, P.; Clavero, M.; Díez-Manguito, M.; Baquerizo, A. Confronting learning challenges in the field of maritime and coastal engineering: Towards an educational methodology for sustainable development. J. Clean. Prod. 2018, 171, 733-742. [CrossRef]

16. Burmeister, M.; Eilks, I. An understanding of sustainability and education for sustainable development among German student teachers and trainee teachers of chemistry. Sci. Educ. Int. 2013, 24, 167-194.

17. Ull, M.; Piñero, A.; Martínez-Agut, M.P.; Minguet, P. Preconcepciones y actitudes del profesorado de magisterio ante la incorporación en su docencia de competencias para la sostenibilidad. Enseñ. Cienc. 2014, 32, 91-112. [CrossRef]

18. Borges, F. Knowledge, Attitudes and Behaviours Concerning Sustainable Development: A Study among Prospective Elementary Teachers. High. Educ. Stud. 2019, 9, 22-32. [CrossRef]

19. Michalos, A.C.; Creech, H.; McDonald, C.; Hatch Kahlke, P.M. Measuring knowledge, attitudes and behaviours concerning education for sustainable development: Two exploratory studies. Soc. Indic. Res. 2011, 100, 391-413. [CrossRef]

20. Michalos, A.C.; Creech, H.; Swayze, N.; Kahlke, P.M.; Buckler, C.; Rempel, K. Measuring knowledge, attitudes and behaviours concerning sustainable development among tenth grade students in Manitoba. Soc. Indic. Res. 2012, 106, 213-238. [CrossRef]

21. Michalos, A.C.; Maurine Kahlke, P.; Rempel, K.; Lounatvuori, A.; MacDiarmid, A.; Creech, H.; Buckler, C. Progress in Measuring Knowledge, Attitudes and Behaviours Concerning Sustainable Development among Tenth Grade Students in Manitoba. Soc. Indic. Res. 2011, 100, 391-413. [CrossRef]

22. Olson, J. Whose voices matter? Gender inequality in the United Nations Framework Convention on Climate Change. Agenda 2014, 28, 184-187. [CrossRef]

23. Olsson, D.; Gericke, N.; Chang Rundgren, S.-N. The effect of implementation of education for sustainable development in Swedish compulsory schools-Assessing pupils' sustainability consciousness. Environ. Educ. Res. 2015, 22, 176-202. [CrossRef]

24. Boeve-de Pauw, J.; Gerikle, N.; Olsson, D.; Berglund, T. The Effectiveness of Education for Sustainable Development. Sustainability 2015, 7, 15693-15717. [CrossRef]

25. Biasutti, M.; Frate, S. A validity and reliability study of the Attitudes toward Sustainable Development scale. Environ. Educ. Res. 2017, 23, 214-230. [CrossRef]

26. Gündüz, S. A Research about attitudes and behaviors of university students with having different cultures towards the environment through sustainable development. EURASIA J. Math. Sci. Technol. Educ. 2017, 13, 1881-1892. [CrossRef]

27. Al-Naqbi, A.; Alshannag, Q. The status of education for sustainable development and sustainabilityknowledge, attitudes, and behaviors of UAE university students. Int. J. Sustain. High. Educ. 2018, 19, 566-588. [CrossRef]

28. Leiserowitz, A.; Smith, N.; Marlon, J.R. Americans' Knowledge of Climate Change; Yale Project on Climate Change Communication; Yale University: New Haven, CT, USA, 2010.

29. Pearson, A.R.; Ballew, M.T.; Naiman, S.; Schuldt, J.P. Race, class, gender and climate change communication. Sustain. Clim. Chang. 2017. [CrossRef]

30. Xiao, C.; McCright, A.M. Explaining Gender Differences in Concern about Environmental Problems in the United States. Soc. Nat. Resour. 2010, 25, 1067-1084. [CrossRef]

31. Ciocoiu, C.M. Integrating digital economy and green economy: Opportunities for sustainable development. Theor. Empir. Res. Urban Manag. 2011, 6, 33-43.

32. Esquivel Alcántara, S.E.; Salgado Vega, M.D.C.; Rodríguez Marcial, R. Empleo Verde y Cambio Climático: Una Disertación. 21 Encuentro Nacional Sobre Desarrollo Regional en México; AMECIDER_ITM: Mérida, México, 2016.

33. López Pardo, I. Sobre el desarrollo sostenible y la sostenibilidad: Conceptualización y crítica. BARATARIA Rev. Castell.-Manch. Cienc. Soc. 2015, 20,111-128. [CrossRef]

34. Lavrinenko, O.; Ignatjeva, S.; Ohotina, A.; Rybalkin, O.; Lazdans, D. The Role of Green Economy in Sustainable Development (Case Study: The EU States). Entrep. Sustain. 2019, 6, 1013-1026. [CrossRef]

35. Loiseau, E.; Saikku, L.; Antikainen, R.; Droste, N.; Hansjürgens, B.; Pitkänen, K.; Thomsen, M. Green economy and related concepts: An overview. J. Clean. Prod. 2016, 139, 361-371. [CrossRef]

36. Vargas Pineda, O.I.; Gonzales, J.M.; Torres Mora, M.A. La economía verde: Un cambio ambiental y social necesario en el mundo actual. Rev. Investig. Agrar. Ambient. 2017, 8, 175-186. [CrossRef] 
37. Geissdoerfer, M.; Savageta, P.; Bockena, N.M.P.; Hultinkb, E.J. The circular economy-A new sustainability paradigm? J. Clean. Prod. 2017, 143, 757-768. [CrossRef]

38. Schroeder, P.; Anggraeni, K.; Weber, U. The Relevance of Circular Economy Practices to the Sustainable Development Goals. J. Ind. Ecol. 2018, 23, 77-95. [CrossRef]

39. ONU. Conferencia de las Naciones Unidas sobre Desarrollo Sostenible Río+20, A/CONF.216/L.1. 2012, p. 12, paragraph 60. Available online: https://rio20.un.org/sites/rio20.un.org/files/a-conf.216-1-1_spanish.pdf.pdf (accessed on 9 March 2020).

40. Prieto-Sandoval, V.; Jaca, C.; Ormazabal, M. Economía Circular: Relación con la Evolución del Concepto de Sostenibilidad y Estrategias para su implementación. Ingeniería 2017, 17, 85-95.

41. Scarpellini, S.; Portillo-Tarragona, P.; Marco-Fondevila, M.; Marín-Vinuesa, L.M.; Valero-Gil, J.; Llera-Sastresa, E.M.; Zabalza-Bribián, I.; Llena-Macarulla, F.; Aranda-Usón, J.A. Píldoras de economía circular en el aula para la enseñanza aplicada en sostenibilidad medioambiental. In Proceedings of the $\mathrm{V}$ Congreso Internacional sobre Aprendizaje, Innovación y Competitividad (CINAIC 2019), Zaragoza, Spain, 9-11 October 2019.

42. European Commision. Communication form the Commission to the European Parliament, the Council, the European Economic and Social Committee of the Regions_Cloosing the Loop-An EU Action Plan for the Circular Economy 2015; COM/2015/0614 final. COM/2015/0614 final; European Commission: Bussels, Belgium, 2015.

43. European Commission. Communication from the Commission to the European Parliament, the Council, the European Economic and Social Committee and the Committee of the Regions. Towards A Circular Economy: A Zero Waste Programme for Europe; COM 2014, 398 Final; European Commission: Bussels, Belgium, 2014.

44. Moneva, J.M.; Portillo-Tarragona, M.P.; Llena-Macarulla, F.; Scarpellini, S. Perspectivas e Impacto de la Economía Circular en Aragón desde la Óptica Empresarial. Econ. Aragon. 2018, 66, 111-126.

45. Aznar, P.; Barron, A. El desarrollo humano sostenible: Un compromiso educativo. Teoría Hist. Educ. 2017, 29, 25-53.

46. Meinzen-Dick, R.; Kovarik, C.; Quisumbing, A. Gender and Sustainability. Annu. Rev. Environ. Resour. 2014, 39, 29-55. [CrossRef]

47. De Silva, D.G.; Pownall, R.A. Going green: Does it depend on education, gender or income? Appl. Econ. 2014, 46, 573-586. [CrossRef]

48. Zelezny, L.C.; Chua, P.P.; Aldrich, C. Elaborating on gender differences in environmentalism. J. Soc. Issues 2000, 56, 443-458. [CrossRef]

49. Vázquez, A.; Massanero, M.A. Actitudes de los jóvenes en relación con los desafíos medio-ambientales. Infanc. Aprendiz. 2005, 28, 309-327. [CrossRef]

50. Connell, S.; Fien, J.; Lee, J.; Sykes, H.; Yencken, D. If it doesn't directly affect you, you don't think about it: A qualitative study of young people's environmental attitudes in two Australian cities. Environ. Educ. Res. 2006, 5, 95-113. [CrossRef]

51. Bear, S.; Rahman, N.; Post, C. The impact of board diversity and gender composition on corporate social responsibility and firm reputation. J. Bus. Ethics 2010, 97, 207-221. [CrossRef]

52. Walls, J.L.; Berrone, P.; Phan, P.H. Corporate governance and environmental performance: Is there really a link? Strateg. Manag. J. 2012, 33, 885-913. [CrossRef]

53. Huang, S.K. The impact of CEO characteristics on corporate sustainable development. Corp. Soc. Responsib. Environ. Manag. 2013, 20, 234-244. [CrossRef]

54. Frias-Aceituno, J.V.; Rodriguez-Ariza, L.; Garcia-Sanchez, I.M. The role of the board in the dissemination of integrated corporate social reporting. Corp. Soc. Responsib. Environ. Manag. 2013, 20, 219-233. [CrossRef]

55. Fernandez-Feijoo, B.; Romero, S.; Ruiz-Blanco, S. Women on boards: Do they affect sustainability reporting? Corp. Soc. Responsib. Environ. Manag. 2014, 21,351-364. [CrossRef]

56. Oerke, B.; Bogner, F.X. Gender, age and subject matter: Impact on teachers' ecological values. Environmentalist 2010, 30, 111-122. [CrossRef]

57. Boeve-de Pauw, J.; Jacobs, K.; Van Petegem, P. Gender Differences in Environmental Values. Environ. Behav. 2012, 46, 373-397. [CrossRef]

58. Liefländer, A.K.; Bogner, F.X. The effects of children's age and sex on acquiring proenvironmental attitudes through environmental education. J. Environ. Educ. 2014, 45, 105-117. [CrossRef]

59. Schwartz, S.H.; Rubel, T. Sex differences in value priorities: Cross-cultural and multimethod studies. J. Pers. Soc. Psychol. 2005, 89, 1010-1028. [CrossRef] [PubMed] 
60. Casimir, G.; Dutilh, C. Sustainability: A gender studies perspective. Int. J. Hum. Resour. Stud. 2003, 7, 316-325. [CrossRef]

61. Torbjörnsson. Measuring Attitudes Towards three Values that Underlie Sustainable Development; Örebro University: Örebro, Sweden, 2011; Volume 20, pp. 97-121.

62. Jacob, B.A. Where the boys aren't: Non-cognitive skills, returns to school and the gender gap in higher education. Econ. Educ. Rev. 2002, 21, 589-598. [CrossRef]

63. Kimmel, M. Boys and School: A Background Paper in the" Boy Crises"; Fritze: Stockholm, Sweden, 2010.

64. Pomerantz, E.M.; Ng, F.F.Y.; Wang, Q. Gender socialization: A parent x child model. In The Psychology of Gender; Eagly, A.H., Beall, A.E., Sternberg, R.J., Eds.; Guilford Press: New York, NY, USA, 2005.

65. Quenzel, G.; Hurrelmann, K. The growing gender gap in education. Int. J. Adol. Youth 2013, 18, 69-84. [CrossRef]

66. Fischer, D.; Brettel, M.; Mauer, R. The Three Dimensions of Sustainability: A Delicate Balancing Act for Entrepreneurs Made More Complex by Stakeholder Expectations. J. Bus. Ethics 2018. [CrossRef]

67. Purvis, B.; Mao, Y.; Robinson, D. Three pillars of sustainability: In search of conceptual origins. Sustain. Sci. 2019, 14, 681-695. [CrossRef]

68. Erdogan, M.; Ok, A.; Marcinkowski, T.J. Development and Validation of Children's Responsible Environmental Behavior Scale. Environ. Educ. Res. 2012, 18, 507-540. [CrossRef]

69. Ugulu, I. Development and Validation of an Instrument for Assessing Attitudes of High School Students about Recycling. Environ. Educ. Res. 2015, 21, 916-942. [CrossRef]

70. Byrne, B.M. Structural Equation Modeling with LISREL, PRELIS, and SIMPLIS: Basic Concepts, Applications, and Programming; Lawrence Erlbaum: Mahwah, NJ, USA, 1998.

71. Kaiser, H.F. The Application of Electronic Computers to Factor Analysis. Educ. Psychol. Meas. 1960, 20, 141-151. [CrossRef]

(C) 2020 by the authors. Licensee MDPI, Basel, Switzerland. This article is an open access article distributed under the terms and conditions of the Creative Commons Attribution (CC BY) license (http://creativecommons.org/licenses/by/4.0/). 